CUSTOMER LOYALTY IN THE DOCTOR'S OFFICE: THE POTENTIAL OF USING
TOOLS LIKE CRM

\author{
Josimar Souza Costa, Federal University of Ceará, josimarscosta@gmail.com \\ José Carlos Lázaro Silva Filho, Federal University of Ceará, lazaro@ufc.br \\ Danielle Batista Coimbra, University of Fortaleza, daniellecoimbra@unifor.br \\ Érico Veras Marques, Federal University of Ceará, ericovmarques@ufc.br \\ Isis Sousa Ferreira, University of Fortaleza, isis@unifor.br \\ Marcelo C. Teixeira Filho, Federal University of Ceará, marcelo-maac@hotmail.com
}

\begin{abstract}
The increase in supplemental medical assistance has made the supply of private medical practice grow over the past few years. Doctors' offices, which used to be simple environments for the interaction between healthcare professional and their patients, have evolved into spaces that are decisive in garnering customer loyalty. Users expect the staff to be mindful, quick and ready to provide information concerning the different options of medical treatment. From this point of view, investments in qualifying medical teams and their staff are a growing requirement. The objective of this article is to evaluate the use of CRM-Customer Relationship Management tools in a gynecologist's office in the city of Fortaleza, aiming to measure the results of this strategy concerning customer loyalty and the resulting optimization of medical prescriptions. This is a descriptive study of a qualitative and quantitative nature. The results obtained allow one to infer that CRM is an effective tool in obtaining customer loyalty, with a direct impact on revenue.
\end{abstract}

Keywords: CRM; doctor's offices; clinics; customer loyalty

\title{
INTRODUCTION
}

Private medical practice has grown considerably over the past few years, mainly due to the increase in supplemental medical assistance. Bahia [1], defines supplemental medical assistance as the option of paying private insurance for access to medical care, independently of compulsory contribution to social security, that includes the right to public assistance through a national health care system.

The market of private medical services is of a mercantile and contractual disposition that, in turn, makes its demand be of a selective nature. From this point of view, this market is composed of those forms of production and management of medical, hospital and clinical services that focus on supplying a distinct demand or restricted body of clients [6].

Within this market are the doctors' offices that have shifted from simple environments for the interaction between physicians and patients to spaces that are decisive in breeding "customer" loyalty. In general, health services are characterized by the high level of contact between service providers and clients[13]. Users expect physicians to give them detailed information, indicating the options for their treatment as well as the advantages and disadvantages of said options. They also expect staff to be courteous, quick and well-prepared. However, this does not always happen, which ends up causing customer insatisfaction.

Presently, it is not merely the experience that users undergo as patients that determines their loyalty, but rather the sum of all the moments they met with in that environment. In this context, investment in qualification is an urgent need, not only for the medical teams, but also for their attending staff. Furthermore, it is also necessary to develop strategies to stimulate these medical teams and staff to rise to the expectations of this particular public. For Spiller 


\section{Issues in Information Systems}

Volume 13, Issue 1, pp. 105-112, 2012

[18], the entire management strategy of a health organization must be lined up to the customers' expectations and to the correct evaluation of their feelings.

It should be pointed out that the target audience of this market has better access to all types of information, and therefore the users require more integrated services, where they have a greater degree of interaction with the physicians and access to their personal health information. The treatment of ailments with quality and safety is no longer sufficient. Patients seek special and individualized therapy, whether at home or at the doctor's office.

Historically, hospital care emerged at the beginning of the Portuguese reign, when religious orders dedicated themselves to curing the ailing. The kings of Portugal were concerned with maintaining a network of Hospitais de Misericódia (Mercy Hospitals), a service a cut above what was to be found on the remainder of the continent. With the Industrial Revolution came the awareness, in the main European countries, that the community was able to protect the health of the workers [15].

Florence Nightingale established the foundations of modern nursing, producing the first medical prescriptions registered on paper with the objective of mitigating mistakes and preventing physicians' orders from being conducted incorrectly, or simply forgotten [8].

In Brazil, as in Europe, physicians worked from their own homes, and their patients were treated at home, consolidating the image of the family doctor.

The need for information from patient history and demographical patient data to outline diagnosis and treatment procedures was supplied through the creation of the medical records. It is composed basically of demographical data, registry of vital signs, evolution of the clinical profile, registry of exams and procedures conducted. The regulation of this document makes it compulsory to fill it in completely, otherwise violating Article 5 of the Code of Medical Ethics.

The "Information Age" forced health services to reorganize their work processes, change the relationship between their professionals and the population, and employ new technology. This adaptation occurred independently of the sector's high level of regulation by trade associations and government authorities.

The Brazilian Federal Medical Authority, by means of its Report 14/93, has released the use of computers for creating electronic patient charts (EPC), providing professional secrecy is upheld.

Speed, elimination of redundancy, reduced filing space compared with paper, sharing, and simultaneous access to information in real time are some of the benefits of consigning data to computers and using the Internet.

In the context of Information Systems the EPC is the main database, allowing the physician to count on the largest amount of data and details of the medical history of each individual patient to support the process of medical diagnosis, and allow for treatment whenever necessary. Furthermore, the EPC is an important source of administrative and psychographical data.

Considering health services as the result of the experiences of the user/customer (in the physician's waiting-room), and then as a patient (during medical examination), the sale of this service is based on the promise of adequately caring for the expectations of the consumer[18]. Building a more trusting and permanent relationship is a challenge for physicians working in their offices. The focal topic of this article is the use of a modern management tool such as Customer Relationship Management (CRM), in doctors' offices, aiming to foresee and understand the needs of the users and help to exceed them.

Considerable competition in this branch of activity and the Brazilian culture of the family doctor, who knows the patient's problem thoroughly, are factors that drive the professionals in this segment to individualize their care and increasingly search for additional personal information that allows them to come closer to their customers.

The use of CRM used to stumble on the high cost and the need for technical knowledge to clearly identify and segment the customer. Nowadays, however, some EPC systems already allow the use of a simple and powerful CRM tool at low cost and with a user-friendly interface. 


\section{Issues in Information Systems}

Volume 13, Issue 1, pp. 105-112, 2012

The overall objective of this article is to evaluate the characteristics of CRM software in a doctors' office, aiming to measure the results of using this tool in obtaining customer loyalty, considering that customer retention represents the continuity of income and the individual value of a customer over time [19].

The study starts from one postulation:

H1: The user of CRM software is able to foresee customer needs and increase the patient loyalty index.

\section{Marketing in Health Services}

The concept of Marketing in health services, stressing its social function, is illustrated by the following paragraph: Marketing represents an instrument capable of delivering a standard of living to society. It should be a motivator of quality of life and is composed of social marketing, in other words, marketing motivated by social causes and directed to them. [3].

Kotler and Keller [12] define marketing as "the social and administrative process whereby individuals and groups obtain what they need and what they want through the creation and exchange of products and values with other persons".

Kotler and Keller [12] also resumes marketing as "caring for customer need with a profit", thus providing a more entrepreneurial view.

Borba [3] says that businesses try to care for the needs and desires of customers aiming to maintain profitability along time. Endurance and permanence of profits in services come about when one knows who the customers are and what they really want and need.

In Brazil, resistance to marketing in the medical and hospital segments is still considerable, due to the old fashioned concept that confuses traditional marketing with sales administration, publishing, promotion and publicity which is ostensive and not adequate to the relations of health assistance [3].

Marketing in health does not stimulate demand, but rather orients to quality and care control, and is a manner of improving services and satisfying customer needs.

\section{Interactive or Relationship Marketing}

Grönroos [11] writes that services are intrinsically of a relational nature. A meeting for the rendering of services, where a patient is examined by a physician, or where he/she makes a telephone call to make an appointment, is a process. A single meeting already includes elements that can lead to a relationship between the parties.

The term relationship contains an ample meaning, and does not just boil down to a greeting when the customer arrives at the doctor's office, nor is it restricted to the moment of the examination. It passes through each point of contact between the patient and the services rendered.

If the final balance of this exchange is positive, a positive perception is generated. If not, then the image that remains is of a service of questionable credibility. Interactive or relationship marketing helps in obtaining a closer understanding of the customer to better care for him, and thus maintain his/her loyalty[10].

According to Grönroos [11], relationship marketing can aim at approximating the organization and its stakeholders, thus providing a much wider scope than just the customer.

The consumer's profile is the basic input of relationship marketing, which will then process this data to compose scenarios that most closely resemble the real needs of the target audience of health organizations, allowing individualized care and obtaining customer loyalty. 


\section{Issues in Information Systems}

Volume 13, Issue 1, pp. 105-112, 2012

The connection between the customer's satisfaction with services rendered and his/her inclination to continue an enduring relationship truly exists, although this behavior is far from being linear[11].

Researches at Xerox indicate that there is a considerable zone of indifference comprised by all those users that do not classify as "very satisfied". Only the "very satisfied" customers show a high repurchase index and great propensity to positive word-of-mouth[11].

Hart and Johnson, quoted by Grönroos [11], came to the conclusion that a business has to go far beyond good service to build loyalty. The organization's customer care always has to reflect reliability in all aspects. This generates "very satisfied" customers who then become unsalaried "salespersons" who spread positive testimony by word of mouth.

In the health business, creating routines for caring for patients is necessary in order for the doctor's office to gain in dexterity, but this requires moderation. This routine is not flexible enough to adapt to the patient at every moment of truth, generating a negative final result [10]

A moment of truth is any episode when a customer makes contact with some aspect of the business, such as persons, installations and equipment, and shapes an impression concerning quality dispensed. The greatest concern of a private doctor's office should be with these critical moments of the process, because these are what will forge the perception of quality of the service in the customer's mind [18].

Spiller [18] also states that special care should be given to two phases of interaction with the customer. The first contact with the customer causes an impression that becomes the organization's calling card. Any failure at this moment generates bad expectations of what will come next, and may cause a customer to renounce, but if corrected in time may encourage the customer to continue. The other phase is the final one, in which failures become ingrained in the customer's mind. It is easier to recover the service in the customer's presence.

Nowadays an essential ingredient to improve relationship marketing is the use of the correct technology to help identify the right customer, his/her distinguishing features and the correct solution for his/her satisfaction [12].

The great competitive advantage sought by health organizations is to turn their eyes upon the customer. To attain this advantage it is necessary to: clearly identify the customer; establish placement strategies for the health professionals and institutions; define organizational objectives; build a relationship of loyalty with all types of customer; adopt strategies that allow building customer trust and loyalty 17.

\section{Customer Relationship Management (CRM)}

In the '90s a new concept emerged in the industry to improve quality in customer care by centralizing all customer information in a system called Customer Relationship Management (CRM). Berry and Linnof [2] understand CRM as a manner of attracting, maintaining and increasing relationships with customers. This understanding is corroborated when one says that CRM implies in relationships focused individually on each buyer, with differentiated attention according to his/her expectations, in such a way as to increase business profitability[16]. In our present stage of development, Information Technology (IT) allows each customer to have personalized care, according to a small group with similar yearnings, no matter to what universe he/she belongs.

A successful relationship with a customer depends on the organization's capacity to remember small details of the relation, and to learn to understand and act in such a way as to surprise the user [16]. Bretzke (2000) unites the strategy of relationship marketing, which cultivates customers and establishes a permanent relationship with them, to the intensive use of information together with IT resources, to define CRM.

Nevertheless, the information system is not an end, but a means, which is why it is a priority to focus on the team, in order to develop the correct attitude in them to obtain the appropriate registry of data, suitable processing and the correct analysis of results obtained [4]. In any case, CRM as a strategy must be united to an integrated business model coordinating a chain of organizations, processes, information and technology [7]. CRM is more than just 


\section{Issues in Information Systems}

Volume 13, Issue 1, pp. 105-112, 2012

dominating a software program. It is a philosophy handled as a doctrine, creating within the organization a cult to the good relationship with the customer in all the stages of the cycle of health care[18].

\section{RESEARCH METHODOLOGY}

Qualitative research with an exploratory disposition, according to Gates and McDaniels Jr. [9] and Malhotra [14], helps to understand the context of the research, and simultaneously provides a better insight of the topic. The objective of this type of research is to identify alternative courses of action, establish key relations to be examined, and identify priorities for derived researches.

The research was based on the case study of a small gynecologist's office, located in the city of Fortaleza in a business center that harbors health organizations and other businesses that help to create demand and convenience for the users. The organization was established in 2008, and counts on a single attendant, two gynecologists and one breast specialist. The business uses a medical information system that basically manages appointments, EPCs, and financial information. Its income in 2009 was approximately $\$ 120,000.00$.

In the qualitative phase research was carried out in books, articles, theses and lectures concerning marketing and quality in health services, CRM and law in force.

In the latter quantitative phase data concerning all patients attended in the lapse of time studied, was collected directly from the database of the EPC system installed in the organization by means of an SQL query, for integration with the Statistical Package for Social Sciences (SPSS). This research considered the variables stored in the EPC from January to June, 2010, considering those pertinent to the loyalty index. This index is calculated by dividing the number of old customers returning during the same time span by the number of old customers using the services of the gynecologist's office. Implementation occurred in April, 2010. By crossing this data one compares the evolution of the indexes in the first two quarters of this year. This evaluation proved that a simple CRM software program predicts the user's needs and acts proactively to satisfy the customer.

\section{RESULTS}

The doctor's office surveyed uses an Electronic Patient Chart with a simple database structure that stores the patients' demographical data and their examination history. The system is integrated online to a dedicated service at the software provider, which allows access to the information 24/7 over the internet. Patient data is stored with a security level comparable to banking systems. The cost of implementing the system was $\$ 300.00$, and the monthly maintenance payment is $\$ 35.00$.

During and Organizational Diagnosis the proprietor expressed interest in reinforcing her relationship with her patients in order to assure their return and their adherence to proposed treatments. After careful analysis the hired consultant identified that the system already in use at the doctor's office had an update that included a CRM mechanism.

The implementation of a CRM mechanism requires a change in paradigms. This implementation is essentially complex, because the organization must make changes in their form of doing business, since all the areas of the organization would now be exerting influence on the client's perception. The success of this implementation depends on the commitment of all the staff [20]. In the case of this doctor's office, the small size and straightforward processes expedited the implementation, since it was not complicated to conduct the essential restructuring of the organization's work processes to guarantee the shared vision defended by Wiersema [20]. Training was conducted remotely by the supplier's support team.

Furthermore, the implementation process was even simpler and quicker because the users were already familiar with the platform that was visually and functionally identical to the system already in use. There was purchase cost for the upgrade, and the monthly payment increased by only $\$ 18.00$. The software integrated the existing information in the initial database to the tool where information compiled by CRM could be extracted. This proves that the EPC 


\section{Issues in Information Systems}

Volume 13, Issue 1, pp. 105-112, 2012

has administrative and marketing functions just as important as those of giving technical support to physicians in their diagnostic decisions and therapeutics.

The system's implementation process consisted of the following phases: Identifying the customer, differentiating the customer, evaluating the customer, and personalizing customer care per group. This process is described by Gregório [10], who grounds all relationship works on four distinct phases, as can be observed in Figure 1:

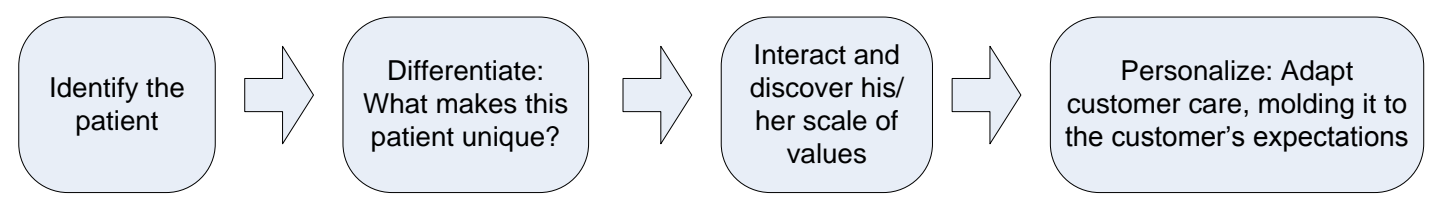

Figure 1: Phases of the process of implementing CRM. Source: Adapted from Gregório [10].

Based on this process the doctor's office evaluated patients according to the following criteria: health insurance plan segmented into classes A, B or C; classification of the customer as new or preexistent; and the type of appointment, such as consultation, colposcopic examination, and other procedures carried out by the physician. This allowed them to associate the elements that compose the main phases of a CRM implementation process.

The resulting classification is illustrated in Table 1, which shows the points given to each criterion.

Table 1. Criteria for Patient Evaluation. Source: Field Research.

\begin{tabular}{|l|l|}
\hline Criterion & Points \\
\hline Health insurance plan type A & 5 \\
\hline Health insurance plan type B & 3 \\
\hline Health insurance plan type C & 1 \\
\hline New customer & 7 \\
\hline Preexisting customer & 10 \\
\hline Type of appointment: consultation & 5 \\
\hline Type of appointment: colposcopy & 7 \\
\hline Type of appointment: procedures & 10 \\
\hline
\end{tabular}

Based on the listed criteria the manager defined customer care priorities by means of a queue of appointments, because one of the important attributes in the decision of a health service consumer is the waiting time until the date of the appointment [10].

If an appointment is cancelled, the application informs which customer shall have priority in having her appointment brought forward, according to the sum of points in her criteria. The system also allows points to be given by other qualitative criteria defined subjectively by the user. Consequently, the order of the appointment queue prioritizes the customers that guarantee greater revenue, and mainly surprises the customer by exceeding her expectations through having her appointment brought forward.

Categorization by type of health insurance plan allowed one to analyze how the calendar was arranged, guaranteeing the availability of appointments for health plans that provided higher income. The Table 2 shows the progression of the loyalty index by health plan.

Table 2. Loyalty index by type of health insurance plan (JAN to JUN/2010). Source: Doctor's Office database

\begin{tabular}{|c|c|c|c|c|c|c|}
\hline Type Month & Jan & Feb & Mar & Apr & May & Jun \\
\hline TYPE A & 0,299 & 0,303 & 0,429 & 0,583 & 0,590 & 0,753 \\
\hline TYPE B & 0,375 & 0,476 & 0,429 & 0,333 & 0,636 & 0,680 \\
\hline \multirow[t]{2}{*}{ TYPE C } & 0,200 & 0,217 & 0,286 & 0,286 & 0,333 & 0,391 \\
\hline & 10,280 & 0,316 & 0,408 & 0,506 & 0,550 & 0,640 \\
\hline
\end{tabular}


An incipient relationship program was started in the clinic in March, with the physicians calling patients on their birthday. This strategy increased the loyalty index by $41.58 \%$ for Type A health plans, and by $29.11 \%$ for the total of patients attended. The physician was collecting birthday information almost by hand, reducing time available for appointments. CRM eliminates this loss by making this query to the database automatic, and consequently increasing the physician's productive capacity by providing her with more time.

The relationship management system was implemented, in effect, in April, resulting in an increase of 56.86\% in total loyalty when compared with March. While health plans A and B together showed a positive variation of $72.03 \%$, the growth for type $\mathrm{C}$ plans increased by $36.71 \%$. This is evidence that the management software does, in fact, increase the loyalty index, as professed in this article.

It is worth pointing out that the impact of CRM is greater on customers that represent more income. Thus, in the long run, the growth of this customer base will escalate income. Ryals [17] points out in his research that greater knowledge of the value of customers leads to changes in the manner they are managed, and should also lead to changes in the organization's strategy.

\section{CONCLUSIONS}

The CRM module used in this doctor's office is not as hefty, nor does it have as many tools, as the software used in medium size and large companies. On the other hand, its relative cost is very low when compared with the gains observed in the process. The quantity of data generated, even in an organization with such simple processes as a doctor's office, must be handled and transformed into information that supports patient-physician and customerdoctor's office relationships. This ratifies the position of several authors who state that information requires actions that generate value for the customers.

The results of this research allow us to conclude that CRM is an efficient tool for the managers of a doctor's office, by foreseeing customers' needs and promoting their loyalty. The use of CRM generates healthier and more longlasting relationships, with a direct impact on the profitability of the business by allowing the physician to create strategies directed mainly to escalate results from the best customers. Further studies are required to examine the applicability of the index of loyalty to a larger time and other types of medical practice, given the limitations of this research.

\section{REFERENCES}

1. Bahia, L. ,(1997) .Planos e seguros saúde no Brasil: características da população coberta. Article presented in the qualification exam for doctorate in social medicine. Rio de Janeiro: IMS/UERJ

2. Berry, M.; Linoff, G. (1999) Mastering Data Mining: The Art and Science of Customer Relationship Management. 1st edition. New York: John Wiley \& Sons, Inc.

3. Borba, V. R. (2009). Estratégias e Plano de Marketing para Organizações de Saúde (Strategies and Marketing Plans for Health Organizations). Rio de Janeiro: Cultura Médica: Guanabara Koogan.

4. Borba, V. R.; Lisboa, T. C.;Ulhôa, W. M. M., (2009). Gestão Administrativa e Financeira de Organizações de Saúde (Administrative and Financial Management of Health Organizations). São Paulo: Atlas.

5. Bretzke, M. (2000). Marketing de relacionamento e competição em tempo real: com CRM (Relationship marketing and competition in real time: with CRM). São Paulo: Atlas,.

6. Burgos, M. T.(1991) Público e privado no sistema de saúde brasileiro: a contextualização do debate em torno dos programas suplementares no setor público (Public and private in the Brazilian health care system: contextualization of the debate concerning supplemental programs in the public sector). Rio de Janeiro: Convênio CEPECS/CASSI.

7. Chan, J.O. (2005). Toward a Unified View of Customer Relationship Management. Journal of American Academy of Business, 6 (1), 32-38.

8. Fraenkel, E. M. História da Enfermagem. Personalidades:Florence Nightingale. Disponível em < http://www.hospvirt.org.br/enfermagem/port/personalidades.htm >. (History of Nursing. Personalities: Florence Nightingale. Available at < http://www.hospvirt.org.br/enfermagem/port/personalidades.htm >. Access on July 13, 2010).

9. Gates, R.; McDaniel Jr., C. (2005). Fundamentos de pesquisa de marketing. $4^{\mathrm{a}}$ edição (Fundaments of marketing research. 4th edition). Rio de Janeiro: LTC. 


\section{Issues in Information Systems}

Volume 13, Issue 1, pp. 105-112, 2012

10. Gregório, R.. (2009). Marketing Médico: criando valor para o paciente (Medical Marketing: building value for the patient). Rio de Janeiro: Editora DOC.

11. Grönroos, C. (2009) .Marketing, gerenciamento e serviços. $3^{\text {a }}$ Edição (Marketing, management and services. 3rd edition). Rio de Janeiro: Elsevier.

12. Kotler, P.; Keller, K. Administração de Marketing (Marketing Administration). São Paulo: Pearson Prentice Hall, 2006.

13. Lovelock, C.;. Wirtz, J. (2006) Marketing de serviços: pessoas, tecnologia e resultados (Service Marketing: People, technology and results). São Paulo: Pearson.

14. Malhotra, N. K.(2006) Pesquisa de marketing: uma orientação aplicada. 4. Ed (Marketing research: applied guidance. 4th Edition). Porto Alegre: Bookman.

15. Morínigo, F. C. Caminhada Médica Brasileira. Serviço de Clínica Médica do H.S.E. - M.S., Rio de Janeiro. Disponível em < http://www.hse.rj.saude.gov.br/profissional/revista/33/camin.asp >.Available at < http://www.hse.rj.saude.gov.br/profissional/revista/33/camin.asp >. Access on: July 10, 2010).

16. Peppers, Don; Rogers, Martha.(1999). Marketing um a um: marketing individualizado na era do cliente. Rio de Janeiro: Campus

17. Ryals, L. (2005). Making Customer Relationship Management Work: The Measurement and Profitable Management of Customer Relationships. Journal of Marketing. 69 (October), 252-261

18. Spiller, E. S..(2009). Gestão dos Serviços de Saúde (The Management of Health Services). Rio de Janeiro: Editora FGV.

19. Vavra, T.G.; Pruden, (1995). D. R. Using aftermarketing to maintain a customer base. Discount Merchandiser. 35( 5), 86-88.

20. Wiersema, F. (1996). Intimidade com o cliente: um compromisso com o resultado dos seus clientes (Familiarity with the customer: a commitment with customers' results). Rio de Janeiro: Campus. 